\title{
Antioxidant and Antinutritional Properties of Biscuit Produced from Enzymatically Modified Tacca [T. Involucrata] Flour
}

ISSN: 2640-9208

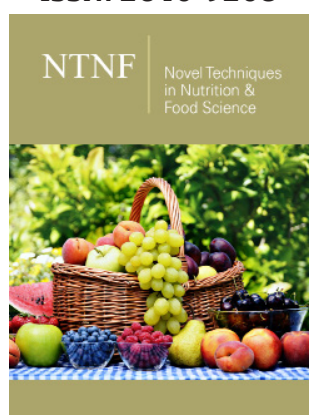

*Corresponding author: Ojewumi Emmanuel Omotayo, Department of Food Science and Technology, Federal University of Technology Akure, Ondo State, Nigeria

Submission: 梅 September 09, 2021

Published: 偪 October 19, 2021

Volume 6 - Issue 2

How to cite this article: Ojewumi EO, Omoba SO, Awolu 00. Antioxidant and Antinutritional Properties of Biscuit Produced from Enzymatically Modified Tacca [T. Involucrata] Flour. Nov Tech Nutri Food Sci. 6(2). NTNF. 000632. 2021. DOI: 10.31031/NTNF.2021.06.000632

Copyright@ Ojewumi EO. This article is distributed under the terms of the Creative Commons Attribution 4.0 International License, which permits unrestricted use and redistribution provided that the original author and source are credited.

\author{
Ojewumi EO*, Omoba SO and Awolu 00
}

Department of Food Science and Technology, Federal University of Technology Akure, Nigeria

\begin{abstract}
In this study antioxidant and antinutritional composition of wheat-tacca [T. involucrata] flour biscuits produced in the following blend ratio: Wheat: enzymatically modifies Tacca flour 95:5, 90:10, 85:15 and 80:20 was analyzed, biscuit produced from $100 \%$ wheat flour was used as control. There was a significant reduction in the antinutritional composition of the composite flour biscuit with increase in substitution. Also, there was a significant increase in the antioxidant properties (Total phenol, DPPH, FRAP, ABTS, OH, Flavonoids), with increase in substitution of wheat flour with enzymatically modified Tacca flour.
\end{abstract}

Keywords: Antioxidant; Antinutrients; Tacca; Enzymatic; Biscuit

\section{Introduction}

Wheat flour is a major raw material in the production of all baked products such as bread, doughnut, biscuits, buns, cakes because of its functional properties [1]. Climatic condition as well as inadequate technology has made it difficult for developing country like Nigeria to grow wheat that is sufficient to meet up with its local domestic demand [2], and hence depend largely on importation of wheat, this in turn affect the economy of the country [3]. For this reason, this research focusses on the possible way of complete or partial replacement of wheat flour with locally grown crop with the aim to reduce cost of baking while enhancing the nutritional functionalities of the baked products.

Composite flour can be described as a mixture of flours from tubers, grains, legumes with or without wheat flour to achieve nutritional composition or functional properties $[4,5]$. Tacca [T. involucrata] is the underground stem tuber with a short-lived storage and regenerative organ developing from a shoot that branch off a mature plant [6], Tacca is an annual herb, which grows upright to a height of $30 \mathrm{~cm}$ and it is widely spread in the savanna zone of Central Africa including Chad, Nigeria and Cameroun which produces an underground tuber which is subject to commercialization in local market for human consumption [7]. Tacca comprises of approximately 15 species of acaulescent forest understory herbs and is included in the family Taccaceae [8].

Biscuits are mostly readily available bakery products worldwide, due to the fact that they are handy, not expensive and can stay longer on the shelf [9]. Producing quality and acceptable biscuits depend largely on the selection of appropeiate flour and right processing steps like fermentation, mixing, aeration, baking and cooling as well as packaging [10]. Biscuits is also considered as low moisture products, this enhance its crispness and crunchiness. It is consumed mostly by children and young adult, it also serves as important tool for food fortification [11]. The objectives of this study are to produce biscuits from varied ratios of wheat flour substituted with tacca flour to improve the nutritional quality; and determine the effect of substitution in the composite formulations on the antioxidant properties and antinutrients composition of the wheat-Tacca flour biscuit. 


\section{Material and Method}

Freshly harvested Tacca (T. involucrata) tubers used for this study were obtained from Eruwa in Oyo state, Nigeria. It was identified at Taxonomy unit of Forestry Research Institute of Nigeria Ibadan, Nigeria, while authentication was done at the Department of Crop, Soil and Pest Management, Federal University of Technology Akure, Nigeria. The chemicals for the analysis were of analytical grade and were obtained from Sigma-Aldrich, London, United Kingdom.

\section{Tacca flour samples preparation}

The freshly harvested tacca tubers were processed into flour using the modified method of [8]. Freshly harvested tacca tubers were washed, manually peeled using stainless steel knife, chopped into smaller pieces, oven dried at $40{ }^{\circ} \mathrm{C}$ (Plus11 Sanyo Gallenkamp PLC, UK) for 8h, pulverized into flour using Kenwood laboratory blender (BLX52 model, UK) and sieved using a 60mm mesh sieve (British Standard) to obtain tacca flour. The flour was packed in a plastic container, sealed and stored at refrigerated temperature $\left(\sim 4^{\circ} \mathrm{C}\right)$ until required for use.

\section{Enzymatic modification of Tacca flour}

Tacca flour starch were modified using enzyme ( $\alpha$-amylase) as described by Mahloko et al. [12] with some modifications [13].

\section{Flour blends formulation}

Based on preliminary analysis, enzymatically modified flour was used in production of biscuit blend with wheat flour. The flours blends were in line with the following Wheat: Tacca flour ratio:
95:5, 90:10, 85:15 and 80:20 respectively. While biscuit produced from $100 \%$ wheat flour was used as control.

\section{Wheat-tacca biscuit}

Wheat-tacca biscuit was produced according to the modified method of $[3,4,14]$.

\section{Determination of Anti-nutrient Composition of enzymatically Modified Tacca Flour}

\section{Determination of saponin content}

The method described by Ndouyang [7] as modified by Olagunju [15] was used to determine the saponin content of flour blend samples.

\section{Determination of alkaloids content}

One gram of flour extract was treated with $10 \mathrm{~mL}$ dilute $\mathrm{HCl}$, gently warmed and filtered. Filtrate was divided into three parts and allowed to react separately with reagents (Mayer's, Dragendroff's and Wagner's). Presence of alkaloids was indicated by the appearance of precipitates and turbidity [16].

\section{Determination of phytate content}

The determination of phytate in sample was done using the method described by Harborne [17].

\section{Determination of oxalate content}

The method described by Abulude [18] was used.

Determination of tannin content

This was done using the method of Ukpabi et al. [19].

\section{Results and Discussion}

\section{Antioxidant properties of wheat-tacca flour biscuits}

Table 1: Antioxidant properties of wheat-tacca composite flour biscuits.

\begin{tabular}{|c|c|c|c|c|c|c|}
\hline Sample & DPPH (\%) & Flavonoid $(\mathbf{m g} / \mathbf{g})$ & Phenols (mg/g) & FRAP (mg/g) & ABTS* $\left.^{*} \%\right)^{\mathrm{m}}$ & OH (\%) \\
\hline Control & $59.90 \pm 1.38^{\mathrm{d}}$ & $0.11 \pm 0.01^{\mathrm{e}}$ & $4.93 \pm 0.32^{\mathrm{d}}$ & $3.03 \pm 0.17^{\mathrm{c}}$ & $35.70 \pm 0.73^{\mathrm{e}}$ & $16.30 \pm 2.20^{\mathrm{c}}$ \\
\hline TEB 5\% & $65.80 \pm 0.42^{\mathrm{c}}$ & $0.20 \pm 0.05^{\mathrm{d}}$ & $8.02 \pm 0.51^{\mathrm{c}}$ & $3.99 \pm 0.01^{\mathrm{b}}$ & $42.80 \pm 5.50^{\mathrm{d}}$ & $17.70 \pm 2.23^{\mathrm{c}}$ \\
\hline TEB 10\% & $68.40 \pm 0.36^{\mathrm{b}}$ & $0.30 \pm 0.00^{\mathrm{c}}$ & $11.60 \pm 0.09^{\mathrm{b}}$ & $7.46 \pm 0.03^{\mathrm{a}}$ & $64.30 \pm 1.32^{\mathrm{c}}$ & $46.60 \pm 6.67^{\mathrm{b}}$ \\
\hline TEB 15\% & $70.50 \pm 0.68^{\mathrm{b}}$ & $0.36 \pm 0.02^{\mathrm{b}}$ & $15.00 \pm 0.03^{\mathrm{a}}$ & $7.45 \pm 0.03^{\mathrm{a}}$ & $81.00 \pm 1.28^{\mathrm{b}}$ & $61.60 \pm 7.22^{\mathrm{a}}$ \\
\hline TEB 20\% & $78.40 \pm 0.47^{\mathrm{a}}$ & $0.48 \pm 0.02^{\mathrm{a}}$ & $15.60 \pm 0.62^{\mathrm{a}}$ & $7.39 \pm 0.02^{\mathrm{a}}$ & $88.30 \pm 1.10^{\mathrm{a}}$ & $68.80 \pm 2.23^{\mathrm{a}}$ \\
\hline
\end{tabular}

Means $( \pm$ SEM) with different alphabetical superscripts in the same column are significantly different at $\mathrm{P}<0.05$.

Key:

TEB 5\%: Wheat-tacca biscuits at 5\% enzymatically modified tacca flour substitution.

TEB 10\%: Wheat -tacca biscuits at 10\% enzymatically modified tacca flour substitution.

TEB15\%: Wheat-tacca biscuits at 15\% enzymatically modified tacca flour substitution.

TEB 20\%: Wheat-tacca biscuits at 20\% enzymatically modified tacca flour substitution.
The antioxidant activities of wheat-tacca flour biscuits are presented in Table 1. The DPPH [Diphenylpicrylhydrazyl] of wheat-tacca biscuit ranges from 59.89\% in control-78.40\% in Tacca Enzymatically Modified Biscuit [TEB20\%]. Results obtained from the present study showed a significant increase in the DPPH scavenging activity with substitution of wheat flour with enzymatically modified flour. The result in this study is similar to previous works of [20] who reported increase in DPPH of biscuits with increased supplementing Cladode Flour (CF) of Opuntia ficusindica.

Flavonoids of Wheat-enzymatically modified tacca flour biscuits ranged from $0.11 \mathrm{mg} / \mathrm{g}$ in control to $0.48 \mathrm{mg} / \mathrm{g}$ in TEB 
$20 \%$. Result obtained shows a significant increase $(\mathrm{p}>0.05)$ with increase in addition of enzymatically modified tacca flour in the order of TEB20\%>TEB15\%>TEB10\%>TEB5\%>Control. This result is similar to the trend obtained in previous work of [9] where total phenolic compounds increased with addition of banana concentrate. The increase in the flavonoids with increase in the addition of enzymatically modified tacca flour might be attributable to the presence of varying phytochemicals including steroidal, diarylheptanoids, phenolic, flavonoids, sesquitepenoids, triterpenoids and starch [8]. The result also agrees with the with the scientific previous discoveries of [21-23] that reported the presence of flavonoid in tacca tuber extract as well as justify the role of the phytochemical present in tacca in controlling high blood pressure. Flavonoids are group of natural substances with variable phenolic structures which possess anticarcinogenic properties; they also displayed antioxidant activities, free radical scavenging properties, heart disease prevention and exhibit potentials for antiimmunodeficiency virus [24].

Table 1 shows that experimental sample might be a good supplement for health-conscious people. The phenols present in wheat-enzymatically modified tacca flour biscuits ranged from $4.93 \mathrm{mg} / \mathrm{g}$ in control to $15.60 \mathrm{mg} / \mathrm{g}$ in TEB20\%, result shows that there was a significant $(p>0.05)$ and progressive increase in the levels of phenols in all the samples in the order of TEB20\%>TEB15\%>TEB10\%>TEB5\%>Control. Similar trend was observed in the work of $[25,26]$ where there was a significant increase in the phenol with substitution of ginger in composite flour used to produce biscuits. The result also agreed with the previous work of [27] who recorded the presence of phenols and other antioxidants in tacca tuber extract. Phenols are names attached to compounds that have one or more hydroxyl groups linked to a 6-carbon aromatic ring [28]. Phenols occurs in food as a secondary metabolite usually in a polymeric polyphenols form and are usually closely associated with sensory and quality of fresh and processed plant food [29]. Phenolic compounds are vital in defense responses, such as anti-aging, anti-inflammatory, antioxidant and antiproliferative activities [28]. Hence, experimental product might be a good source of anti-aging and anti-inflammation supplement [30].

The Ferric Reducing Antioxidant Power (FRAP) of wheatenzymatically modified tacca flour biscuits is also presented in Table 1 . The ability to reduce $\mathrm{Fe}^{3+}$ exhibited by Wheat-enzymatically modified tacca flour biscuits ranged from $3.03 \mathrm{mg} / \mathrm{g}$ in control $-7.39 \mathrm{mg} / \mathrm{g}$ in TEB $20 \%$. Where $100 \%$ wheat flour biscuits were used as control, and it exhibited $\mathrm{Fe}^{3+}$ reducing ability of $3.03 \mathrm{mg} / \mathrm{g}$. The reducing ability was in dose dependent manners which increase with increase in the substitution of wheat flour with enzymatically modified tacca flour. $\mathrm{Fe}^{3+}$ reduction power is often used as an indicator in-vitro determination of reducing power of pure food substances [31]. The reducing power usually relied solely on the presence of a reducing agent (antioxidant) which crystallizes antioxidant activity by breaking the free radical chains through donation of a hydrogen atom. It observed that from the results obtained that TEB20\% exhibited the highest $\mathrm{Fe}^{3+}$ reducing power and next to it is TEB15\% < TEB10\%, TEB5\%. This implies that enzymatically modified tacca flour contributed to an enhanced reduction of $\mathrm{Fe} 3+$ complex experienced in all the biscuits samples. This is an indication that antioxidants present in plant might also be a contributing factor to enhanced antioxidant activities in experimental sample [32].

Table 1 shows the ABTS* Radical Scavenging Activity (ARSA) of wheat-enzymatically modified tacca flour biscuits. The value ranged from $35.70 \%-88.30 \%$. TEB20 had the highest value of $88.30 \%$ and the highest scavenging activity against the ABTS*, TEB15 was next in ABTS* scavenging activity while TEB5\% had the least scavenging ability of $42.80 \%$, whereas $100 \%$ wheat biscuits was used as control with ABTS* scavenging activity of $35.70 \%$. All the biscuits samples exhibited a stronger antioxidant scavenging ability against ABTS* relative to the control, it was however observed that ABTS* radical scavenging activity increase with increase in the ratio of enzymatically modified tacca flour, indicating the influence of tacca flour on the ABTS* scavenging ability justifying the finding [31], who reported the presence of phytochemicals/antioxidants in extract of tacca. Result is also consistent with the previous findings of [9] where there was an increase in the ABTS* radical scavenging activity in biscuits made with wheal-prickly heat and banana flour, result of this research shows that experimental sample might be a very good source of antioxidant.

The hydroxyl $\left(\mathrm{OH}^{*}\right)$ radical scavenging ability of wheatenzymatically modified tacca biscuits is shown in Table 1 . Value ranged from $16.30 \%-68.80 \%$ result shows that $\mathrm{OH}^{*}$ scavenging activity of wheat-enzymatically modified tacca flour biscuits were concentration dependent, increasing with the increase in substitution of wheat with enzymatically modified flour at different ratio. TEB20\% had the highest hydroxyl radical scavenging ability of $68.80 \%$ followed by TEB15\% with $\mathrm{OH}^{*}$ scavenging ability of $61.60 \%$, then TEB10\% with $\mathrm{OH}^{*}$ scavenging ability of $46.40 \%$ and the TEB5\% with the least enzymatically modified tacca flour inclusion having $\mathrm{OH}^{*}$ scavenging ability of $17.70 \%$ which happens to be the least $\mathrm{OH}^{*}$ radical scavenging ability. $100 \%$ biscuits were used as a control. This increase might be influenced by the antioxidant present in the tacca flour, this result agrees with the previous findings $[8,31,32]$.

An increase in the free radical scavenging properties in baked products is mostly associated with the antioxidant properties present [33]. The improvement of free radical scavenging properties in the biscuits would therefore be of great necessity from the point of consumption. In the present study, $\mathrm{OH}^{*}$ radical scavenging activity, ABTS*, FRAP, Phenols and Flavonoids content of the biscuit samples increased in a concentration-dependent manner (increasing amount of tacca enzymatically modified flour).

\section{Antinutritional properties of wheat-tacca biscuits}

The alkaloid content of wheat enzymatically modified flour biscuit as presented in Table 2 ranged from 10.70- 4.23\%. There was a significant reduction $\mathrm{p}<0.05$ in the alkaloids content in the 
biscuit samples with increase in the enzymatically modified tacca flour, although there was a slight increase in the alkaloid content in TEB20\% when compared with TEB10\% and TEB15\%. This may be attributed to the level of enzymatically modified flour being added. It has been reported that various processing technique like cooking and soaking greatly reduce the level of alkaloids in foods [34].

Table 2: Antinutritional properties of wheat-Tacca biscuits.

\begin{tabular}{|c|c|c|c|c|c|}
\hline Sample & Alkaloids (\%) & Phytate $(\mathbf{m g} / \mathbf{g})$ & Oxalate $\mathbf{( m g} / \mathbf{g})$ & Saponin $(\mathbf{m g} / \mathbf{g})$ & Tannins $(\mathbf{m g} / \mathbf{g})$ \\
\hline Control & $10.70 \pm 0.53^{\mathrm{a}}$ & $4.22 \pm 0.11^{\mathrm{a}}$ & $42.40 \pm 0.08^{\mathrm{a}}$ & $570.00 \pm 20.20^{\mathrm{a}}$ & $0.11 \pm 0.01^{\mathrm{a}}$ \\
\hline TEB 5\% & $10.30 \pm 0.09^{\mathrm{a}}$ & $4.27 \pm 0.16^{\mathrm{a}}$ & $38.80 \pm 0.68^{\mathrm{b}}$ & $517.00 \pm 66.70^{\mathrm{b}}$ & $0.10 \pm 0.02^{\mathrm{a}}$ \\
\hline TEB 10\% & $4.02 \pm 0.42^{\mathrm{c}}$ & $2.43 \pm 0.04^{\mathrm{b}}$ & $42.00 \pm 0.27^{\mathrm{a}}$ & $522.00 \pm 29.90^{\mathrm{b}}$ & $0.09 \pm 0.01^{\mathrm{b}}$ \\
\hline TEB 15\% & $4.43 \pm 0.08^{\mathrm{c}}$ & $2.32 \pm 0.14^{\mathrm{b}}$ & $41.40 \pm 0.02^{\mathrm{a}}$ & $540.00 \pm 2.78^{\mathrm{b}}$ & $0.09 \pm 0.01^{\mathrm{b}}$ \\
\hline TEB 20\% & $5.25 \pm 0.06^{\mathrm{b}}$ & $0.98 \pm 0.20^{\mathrm{c}}$ & $41.20 \pm 0.21^{\mathrm{a}}$ & $453.00 \pm 1.40^{\mathrm{c}}$ & $0.08 \pm 0.01^{\mathrm{b}}$ \\
\hline
\end{tabular}

Means $( \pm$ SEM) with different alphabetical superscripts in the same column are significantly different at $\mathrm{P}<0.05$.

Key:

TEB 5\%: Wheat-tacca biscuits at 5\% enzymatically modified tacca flour substitution.

TEB10\%: Wheat -tacca biscuits at 10\% enzymatically modified tacca flour substitution.

TEB15\%: Wheat-tacca biscuits at 15\% enzymatically modified tacca flour substitution.

TEB 20\%: Wheat-tacca biscuits at 20\% enzymatically modified tacca flour substitution.

The phytate content of wheat-tacca biscuits ranged from $4.22 \mathrm{mg} / \mathrm{g}$ in control- $0.98 \mathrm{mg} / \mathrm{g}$ in TEB20\%. There was a significant reduction of $\mathrm{p}<0.05$ in phytate content from TEB5\%>TEB10\%>TEB15\%>TEB20. It was observed that the reduction was proportional to the substitution of wheat flour with enzymatically modified flour, which suggests that enzymatically modified flour might have phytate content less that than that in wheat flour. Which resulted to a lower phytate recorded in wheatenzymatically modified tacca flour biscuits. Hence the biscuit may be regarded as safe for consumption not having any deleterious effect on iron, calcium and Zinc bioavailability as the phytate content is less than recommended per day requirement of $2500 \mathrm{mg}$ [35]. Finding in this research is similar to the previous work of [4] who reported a reduction in phytate content of biscuits produced with malted sorghum-soy composite flour with increase in soy flour substitution.

Oxalate content in composited wheat-enzymatically modified tacca biscuits ranged from $38.80 \mathrm{mg} / \mathrm{g}$ in TEB5\%- $41.20 \mathrm{mg} / \mathrm{g}$ in TEB20\%, while biscuit made with, $100 \%$ wheat flour used as control has $42.40 \mathrm{mg} / \mathrm{g}$ oxalate. There was a significant increase in the oxalate content of the experimental sample although not in a particular sequence but a marginal increase with increase in substitution of wheat flour with enzymatically modified tacca flour, however TEB5\% recorded the highest oxalate content. Saponin content of wheat- enzymatically modified tacca flour ranged from $517.00 \mathrm{mg} / \mathrm{g}$ in TEB5\%-453.00mg/g in TEB20\%, while its content in biscuits made with $100 \%$ wheat flour as control is $570.00 \mathrm{mg} / \mathrm{g}$. Although there was a reduction in the saponin content with increase in the substitution of wheat flour with enzymatically modified flour, however, TEB15\% though lower than control, recorded the highest Saponin content among the entire sample.

Tannins in wheat-enzymatically modified tacca flour ranges from $0.10 \mathrm{mg} / \mathrm{g}$ in TEB5\% and $0.08 \mathrm{mg} / \mathrm{g}$ in TEB20\%. Its content in biscuits made with $100 \%$ wheat flour as control is $0.11 \mathrm{mg} / \mathrm{g}$, the finding revealed a significant $\mathrm{p}<0.05$ decrease in tannin in the composite flour biscuit with the degree of substitution of wheat flour with enzymatically modified tacca flour. This result is consistent with the previous study where there was a significant reduction in the tannin content of cookies produced from a blend of Cassava, wheat and cowpea flours [36]. The result obtained in this research is consistent with the finding of previous researcher who stated that tacca is very rich in all the above listed antinutrients, however soaking, boiling and other processing methods have capability of reducing it by more than half $[8,37]$.

\section{Conclusion}

In the present study, the results shows that blends of wheat flour and enzymatically modified tacca flour at various ratio in producing cookies resulted into improved quality characteristics which varies with the degree of substitution. As the levels of tacca flour increased the antioxidant properties increased significantly $(\mathrm{P}>0.05)$, this significant increase was consistent with substitution of wheat flour with tacca flour ranging from $20 \%>15 \%>10 \%>5 \%$, while the antinutritional composition also reduces with substitution, this reduction was also consistent with increase in substitution. However, the cookies characteristics for all the samples demonstrate the suitability of the wheat tacca blends up to $20 \%$ to produce health friendly cookies.

\section{References}

1. Adeleke RO, Odedeji JO (2010) Functional properties of wheat and sweet potato flour blends. Pakistan Journal of Nutrition 9(6): 535-538.

2. David M (2006) Nigeria no. 1 market for US wheat; potential for other grains and feeds. USAID Foreign Agricultural Service Bulletin 21: 1-2.

3. Ohimain EI (2014) The prospects and challenges of cassava inclusion in wheat bread policy in Nigeria. International Journal of Science, Technology and Society 2(1): 6-17.

4. Olapade AA, Adeyemo MA (2014) Evaluation of cookies produced from blends of wheat, cassava and cowpea flours. International Journal of food studies Volume 3. 
5. Noorfarahzilah M, Lee JS, Sharifudin MS, Fadzelly MA, Hasmadi M (2014) Applications of composite flour in development of food products. International Food Research Journal 21(6): 2061-2074.

6. Nwokocha L (2017) Chemical composition and rheological properties of white and yellow Tacca Involucrata flours. Nigerian Journal of Science 51(1): 57-63.

7. Ndouyang CJ, Njintang NY, Facho B, Scher J, Mbofung CM (2015a) Effect of Processing Method on the Antinutrient Content of Tacca leontopetaloides L. Kuntze Flour. British Journal of Applied Science \& Technology 5: 258.

8. Ndouyang C, Nguimbou R, Njintang Y, Scher J, Facho B, et al. (2014) In vivo assessment of the nutritional and subchronic toxicity of Tacca leontopetaloides (L.) tubers. Scholars Academic Journal of Pharmacy 3: 53-60.

9. Ndouyang CJ, Njintang NY, Facho B, Scher J, Mbofung CM (2015b) Effect of processing method on the antinutrient content of Tacca leontopetaloides L. Kuntze flour. Current Journal of Applied Science and Technology 5(3): 258-269.

10. Jiang J, Yang H, Wang Y,Chen Y (2014) Phytochemical and pharmacological studies of the genus Tacca: a review. Tropical Journal of Pharmaceutical Research 13(4): 635-648.

11. Mahloko L, Silungwe H, Mashau M, Kgatla T (2019a) Bioactive compounds, antioxidant activity and physical characteristics of wheatprickly pear and banana biscuits. Heliyon 5(10): e02479.

12. Mahloko LM, Silungwe H, Mashau ME, Kgatla TE (2019b) Bioactive compounds, antioxidant activity and physical characteristics of wheatprickly pear and banana biscuits. Heliyon 5(10): e02479.

13. Agu HO, Ezeh GC, Jideani AIO (2014) Quality assessment of Acha-based biscuit improved with Bambara nut and unripe plantain. African Journal of Food Science 8(5): 278-286

14. Oyeyinka SA, Oyeyinka AT, Karim OR, Toyeeb KA, Olatunde SJ, et al. (2014) Biscuit making potentials of flours from wheat and plantain at different stages of ripeness. Croatian Journal of food science and Technology 6(1): 36-42.

15. Olagunju AI, Omoba OS, Enujiugha VN, Wiens RA, Gough KM, et al (2020) Influence of acetylation on physicochemical and morphological characteristics of pigeon pea starch. Food Hydrocolloids 100: 105424

16. Aliyu AB, Musa AM, Oshanimi JA, Ibrahim HA, Oyewale AO (2008) Phytochemical analyses and mineral elements composition of some medicinal plants of Northern Nigeria. Nigerian Journal of Pharmaceutical Sciences 7(1): 119-125.

17. Harborne JB (1973) Phenolic compounds. In: Phytochemical methods. Springer, Dordrecht, Netherlands, pp. 33-88.

18. Abulude FO (2004) Effect of processing on nutritional composition, phytate and functional properties of rice (Oryza sativa $L$ ) flour. Nigerian Food Journal 22(1): 97-104.

19. Ukpabi U, Ukenye E, Olojede A (2009) Raw Material Potentials of Nigerian Wild Polynesian Arrowroot (Tacca leontopetaloides) Tubers and Starch. Journal of Food Technology 7(4): 135-138.

20. Medoua GN, Mbome IL, Egbe TA, Mbofung CMF (2007) Antinutritional factors changes occurring in trifoliate yam (Dioscorea dumetorum) tubers after harvest. Food Chemistry 102(3): 716-720.

21. Nabil B, Ouaabou R, Ouhammou M, Essaadouni L, Mahrouz M (2020) Functional properties, antioxidant activity, and organoleptic quality of novel biscuit produced by moroccan cladode flour "Opuntia FicusIndica". Journal of Food Quality 2020.

22. Betalini WH, Andri FM, Tri ME (2016) Growth, phytochemical content, and antioxidant activity of in vitro gamma irradiated Tacca (Tacca leontopetaloides) plant. AIP Conference Proceedings 2199(1).

23. Jamaludin FL, Mohamad J (2016) Antihypertension activity of water extract of tacca integrifolia. Sains Malaysiana 45(3): 425-433.

24. Vu QTH, Le PTK, Vo HPH, Nguyen TT, Nguyen TKM (2017) Characteristics of Tacca leontopetaloides L. Kuntze collected from an Giang in Vietnam. AIP Conference Proceedings 1878: 020022.

25. Yao LH, Jiang YM, Shi J, Barberan FT, Datta N, et al. (2004) Flavonoids in food and their health benefits. Plant foods for human nutrition 59(3): 113-122.

26. Vidak M, Rozman D, Komel R (2015) Effects of flavonoids from food and dietary supplements on glial and glioblastoma multiforme cells. Molecules 20: 19406-19432.

27. Fabusiwa FJG, Oladele E, Oboh G, Adefegha S, Fabusiwa O, et al. (2019) Glycemic response in diabetic subjects to biscuits produced from blends of pigeon pea and wheat flour. Plant Foods for Human Nutrition 74(4): 553-559.

28. Fabusiwa FJG, Oladele EP, Oboh G, Adefegha SA, Oshodi AA (2018) Polyphenol contents and antioxidants activities of biscuits produced from ginger-enriched pigeon pea-wheat composite flour blends. Journal of Food Biochemistry 42(4): e12526.

29. Jagtap S, Satpute R (2014) Phytochemical screening and antioxidant activity of tuber extracts of Tacca pinnatifida Jr \&J. G. Forst. International Journal of Recent Trends in Science and Technology 9(3): 389-396.

30. Delgado AM, Issaoui M, Chammem N (2019) Analysis of main and healthy phenolic compounds in foods. Journal of AOAC International 102(5): 1356-1364.

31. Lim T (2016) Tacca leontopetaloides. In: Edible Medicinal and NonMedicinal Plants. Springer, Germany.

32. Gülçin I (2015) $\mathrm{Fe}^{3+}-\mathrm{Fe}^{2+}$ transformation method: an important antioxidant assay. Advanced Protocols in Oxidative Stress III. Springer, Germany.

33. Nurraihana H, Hanoon NN, Hasmah A, Wan R (2017) Phytochemical and antioxidant potential of four traditional Malaysian medicinal plants. Journal Tropical Resources Sustainable Science 5(1): 9-14.

34. Chakraborty P, Mittal P, Gupta MS, Yadav S, Arora A (2021) Opinion of students on online education during the COVID-19 pandemic. Human Behavior and Emerging Technologies 3(3): 357-365.

35. Abeshu Y, Kefale B (2017) Effect of some traditional processing methods on nutritional composition and alkaloid content of lupin bean. International Journal of Bioorganic Chemistry 2(4): 174-179.

36. Hambidge KM, Miller LV, Westcott JE, Krebs NF (2008) Dietary reference intakes for zinc may require adjustment for phytate intake based upon model predictions. The Journal of Nutrition 138: 2363-2366.

37. Feyera M (2020) Review on some cereal and legume based composite biscuits. International Journal of Agricultural Science and Food Technology 6(2): 101-109. 